\title{
The Effects of Memory and Social Strategies on Oral Production $^{1}$
}

\section{Los Efectos de Estrategias Sociales y de Memoria en la Producción Oral}

\author{
Tania Henríquez ${ }^{2}$ \\ Harry Von ${ }^{3}$ \\ Victor Peña ${ }^{4}$ \\ Elena Adriana Llanquileo 5
}

Citation/ Para citar este Artículo: Henríquez T., Von H., Peña V. \& Llanquileo E. (2017). The Effects of Memory and Social Strategies on Oral Production, 19(2), pp. XX-XX.

Received: 06-Jun-2016 / Accepted: 20-May-2017

DOI: http://dx.doi.org/10.14483/calj.v19n2.10535

\begin{abstract}
Language learning strategies (LLS) play a significant role in enhancing learning (Hedge, 2000; Oxford, 1990, 2003). In spite of this, little attention has been given to LLS in oral production in English as a second language (ESL) in Chile. This quasi-experimental research aimed to improve learners' oral production achievements through a direct instruction period (DIP) of memory and social learning strategies. The participants included 10 eleventh grade students from a state-subsidized school. Both qualitative and quantitative instruments were used to collect data including: ethnographic field notes, surveys, and a pre/post-test. Moreover, due to sample size, non-parametric statistics were used to analyze the results obtained from the pre- and post-tests. Results showed that students' oral production improved as a result of the memory instruction and social strategies suggesting that the former is more influential than the latter. These findings also suggest that a change in teaching methodologies and sample size might have influenced the results.
\end{abstract}

Keywords: memory strategies, oral production, social strategies

\section{Resumen}

Las estrategias de aprendizaje de idiomas cumplen un rol significativo en promover el aprendizaje (Hedge, 2000; Oxford, 1990, 2003). Sin embargo, en Chile no se ha dado mayor importancia a las estrategias de aprendizaje de idiomas en la producción oral en inglés como segunda lengua. Este estudio cuasi experimental tenía como propósito mejorar los niveles de producción oral mediante estrategias de aprendizaje de memoria y sociales durante un periodo de intervención directa. Los participantes fueron 10 estudiantes de tercero año de enseñanza secundaria de un colegio privado con aportes del estado. Se utilizó instrumentos cuantitativos y cualitativos para recolectar la información: notas etnográficas, encuestas, y pruebas de entrada y salida. Además, debido al tamaño reducido de la muestra, los

1 This research project was carried out as an internal research project, supported by the English Teaching and Translation Program and the Art and Humanities Department from Universidad de Los Lagos, Chile.

2 Universidad de Los Lagos, Osorno, Chile. tania.katina@hotmail.com

3 Universidad de Los Lagos, Osorno, Chile. harry.vjn@gmail.com

4 Universidad de Los Lagos, Osorno, Chile. victor.pena@ulagos.cl

5 Universidad de Los Lagos, Osorno, Chile. ellanquileo@ulagos.cl 
resultados obtenidos en las pruebas de entrada y salida fueron analizados a través de estadísticas no-paramétricas. Los resultados finales mostraron que los estudiantes mejoraron gracias a la instrucción de estrategias sociales y de memoria, siendo esta última las más influyentes. Estos hallazgos sugieren que un cambio en la metodología de enseñanza y el tamaño la muestra también pudieron influenciar los resultados.

Palabras clave: estrategias de memoria, estrategias sociales, producción oral

\section{Introduction}

Speaking has been one of the skills learners have least developed in schools in Chile in spite of the importance that the Chilean Government has placed on the English curriculum. Notwithstanding, the 2012 SIMCE $^{6}$ (Sistema de Medición de Calidad de la Educación) results did not achieve the expected standards in regards to reading and speaking skills. These results revealed the low level of English of secondary students indicating that more than $80 \%$ are not able to understand simple oral or written texts (Mineduc, 2012). It can be inferred from these results that Chilean learners' proficiency, in terms of receptive skills, might not be fully developed. Moreover, if reading and listening function as input to develop productive skills, the lack of comprehensible input might affect learners' second language acquisition (Ellis, 1997, p. 44). According to Krashen, if there is an appropriate level of input, speakers will succeed in making themselves understood in communication (Krashen, 1993).

Since the early 1970s, second language acquisition (SLA) theories and approaches have become more communicative in nature (Demirezen, 2011; Richards \& Rodgers, 2001, p. 71). Speaking as a language skill has shifted away from repeating and memorizing a given dialog or drilling into a language skill that promotes communicative competence and fluency (Richards, 2008). This language skill now involves an interactive process in which the construction of meaning is achieved by receiving, processing, and producing information (Lazaraton, 2011). Though recent research in this area focuses on the development of this skill, other conditions seem to be relevant for improving overall speaking performance. With regard to this matter, language

6 Education National Measurement System : Standardized test that measures learner's competences in given subjects or areas such as English, Spanish, and Math. learning strategies might play a central role in this process. For instance, since speaking involves social skills, social strategies may help learning to interact and may resemble real interactions (Oxford, 1990). Likewise, since learning requires memory, memory strategies might help learners to store, memorize, and retrieve lexical chunks to enhance speaking (Thornbury, 2010).

This quasi-experimental study focuses on students' difficulties when expressing ideas orally; therefore, it represents an initial investigation into the effects that memory and social strategies have on oral production of 10 eleventh graders from a subsidized school in Chile.

\section{Literature Review}

The ability to speak in a second language/ foreign language involves production and interaction meaning that a speaker has to cope with managing speaking turns while simultaneously co-operating with others during the process. Furthermore, as spoken language is carried out during social interactions, the speaker usually does not have sufficient time to plan speech. Thornbury (2010) states that:

In these circumstances, spoken fluency requires the capacity to marshal a store of memorized lexical chunks. And the nature of speaking process means that the grammar of spoken language differs in a number of significant ways from the grammar of written language. (p. 10)

In light of the above mentioned conditions, a speaker should handle various levels of complexity, from extra-linguistic to linguistic knowledge, which is almost intuitive for our first language. However it is important when learning a foreign language to 
be aware of elements such as: vocabulary, genre, grammar, phonology, discourse, pragmatic, and socio-cultural knowledge (Thornbury, 2010). For speaking purposes, these six dimensions comprise the following characteristics:

1. Vocabulary: the selection of words or phrases should be based on the "frequency" criterion, i.e., the most common words.

2. Genre: a type of speech event and how it can be labelled by participants.

3. Grammar: direct and simple constructions to favor rapid and real time speech production.

4. Phonology: encourage basic differentiations in pronunciation and intonation.

5. Discourse: structure utterances according to specific genre's conventions.

6. Pragmatic: interpret, perform, or adjust the message according to the context.

7. Socio-cultural: manage and develop intercultural competence (codify socio-cultural rules).

8. (Thornbury, 2010, pp. 11-26)

In addition to the above features, there are relevant purposes for speaking. In real conversations, people have different reasons to produce oral speech. Thus, theory suggests the following classification of specific purposes.

1. Interactional: people communicate for social purposes. This includes establishing and maintaining social relationships.

2. Transactional: involves communicating to get something done, including the exchange of goods and services.

3. Performance: the speaker produces longer stretches of discourse by emphasizing monologues rather than dialogues (Richards, 2017, pp. 2-6).

\section{Learning Strategies: Operations Employed by the Learner}

According to Oxford (1990), "learning strategies are steps taken by learners to enhance their own learning" (p. 1). Regarding language learning, the importance of the use of strategies lies in the development of communicative competence, which in turn can improve learners' oral production.
There are two types of learning language strategies: direct and indirect strategies.

On the one hand, direct strategies deal with the language itself by demanding mental processes. On the other hand, indirect strategies support the cognitive process of learning a language without using the target language directly.

Bearing in mind the previous points, memory and social strategies were the strategic tools used to enhance language learning and encourage oral production during the intervention period. Memory strategies are connected with the vocabulary and utterances that should be stored in mind. Social strategies are focused on interaction - the essential feature of speaking skills.

\section{Memory Strategies}

Memory strategies are techniques that help learners to store data effectively. For example, arranging things in order, making associations, and reviewing are useful tools to remember what has been learned before and then to recall the information in the present, when necessary. To store a large amount of vocabulary and patterns, rehearsal and awareness on the use of these strategies may lead the student to an automatic skill level (Oxford, 1990).

Memory strategies are divided into four substrategies: creating mental linkages, applying images and sounds, reviewing well, and employing action. Some of these are closely connected with cognitive style preferences. Therefore, these strategies invite learners to take advantage of their own abilities and improve them by practicing these (Oxford, 1990). The following chart summarizes these sub-strategies.

From these ten strategies, only three were emphasized to promote oral speech during the direct intervention period (DIP). Placing new words into context, using imagery, and structured reviewing were emphasized in order to focus and narrow down the DIP. 
Table 1. Memory Strategies

\begin{tabular}{|c|c|c|}
\hline \multirow{10}{*}{ Memory Strategies } & \multirow{3}{*}{ Creating mental linkages } & 1. Grouping \\
\hline & & 2. Associating/Elaborating \\
\hline & & 3. Placing new words into a context \\
\hline & \multirow{4}{*}{ Applying images and sounds } & 1. Using imagery \\
\hline & & 2. Semantic Mapping \\
\hline & & 3. Using key words \\
\hline & & 4. Representing sound in memory \\
\hline & Reviewing well & 1. Structured reviewing \\
\hline & \multirow{2}{*}{ Employing action } & 1. Using physical response or sensation \\
\hline & & 2. Using mechanic techniques \\
\hline
\end{tabular}

(Oxford, 1990: 18)

1. Placing new words into a context allows the students to remember vocabulary or sentences by giving them a meaningful context, i.e., isolated words will turn into significant chunks. Hence, they should be easy to recall when spoken communication occurs (Oxford, 1990).

2. Using imagery helps to remember new vocabulary or phrases when speaking by recalling the images that the words represent for the learners. This strategy enables the learner to make use of visual storage intelligence which is the most used by learners in general. Additionally, there is research that proposes a close relationship between visual memory and visual mental imagery by suggesting that these two share the same neural controller (Slotnick, Thompson, \& Kosslyn, 2012).

3. Structured Reviewing acts as a major complement because the constant rehearsal will lead the learner to reach an automatic or natural level of communication (Oxford, 1990).

Most young learners do not use these strategies at all, and if they execute any strategy, commonly the results do not benefit the students' memory performance (Schneider, Kron-Sperl, \& Hünnerkopf, 2009). Therefore, assuming that the participants' cognitive level is appropriate for training in memory strategies, this period of instruction was expected to benefit these students' competent memory strategy use, and thus contribute to the development of their speaking skills (Thornbury, 2010, p. 23).

\section{Social Strategies}

Social strategies are indirect language learning strategies that help students to improve their English proficiency levels by giving support and facilitating the cognitive process of learning another language. Oxford asserts that "social strategies help students learn through interacting with others" (Oxford, 1990 , p. 135). Therefore, they act as useful tools to assist the learner when facing speaking activities. As mentioned above, the essence of speaking lies on the interaction and communication among people. Therefore, the use of social strategies helps students to improve and increase the opportunities to use the target language. As with memory strategies, social strategies are also divided into three categories, which are sub-divided into two specific strategies.

1. Asking questions: these strategies involve asking someone, possibly a teacher or a proficient classmate, for clarification, verification, or correction.

2. Cooperating with others: involves interacting with one or more people to improve language skills (group or pair work).

3. Empathizing with others: taking into consideration others' beliefs and thoughts.

(Oxford, 1990, p. 147)

Social strategies also helped to create a comfortable atmosphere within the classroom and improve students' mutual support. For the purpose 
Table 2. Social Strategies

\begin{tabular}{|c|c|c|}
\hline \multirow{4}{*}{ Social Strategies } & Asking questions & 1. Asking for clarification \\
\hline & \multirow{2}{*}{ Cooperating with others } & 1. Cooperating with peers \\
\hline & & 2. Cooperating with proficient users. \\
\hline & Empathizing with others & $\begin{array}{l}\text { 1. Developing cultural understanding. } \\
\text { 2. Becoming aware of other thought and feelings. }\end{array}$ \\
\hline
\end{tabular}

(Oxford, 1990: 21)

of this study, all of these strategies, in one way or another, were considered and developed during the intervention period. The strategies listed above were the ones implemented in every lesson during the intervention period in different ways such as dialogues, oral presentation, talks, acting, or any pair/group activity with appealing and interesting topics, thus giving students the possibility to ask questions to solve doubts, cooperate, and help their classmates by making comments and giving opinions about their work.

\section{Methodology}

This quasi-experimental study comprises both quantitative and qualitative methods, which provide the researcher with numerical and non-numerical data, respectively (one instrument providing numerical data and two providing non-numerical data). This mixed-method approach facilitates a multilevel analysis and a wider combination of data sources to study the same social phenomenon; therefore, "using a mixed method approach increases the likelihood that the sum of the data collected will be richer, more meaningful, and ultimately more useful in answering the research questions" (Johnson, Onwuegbuzie, \& Turner, 2007, p. 121). The research questions that guided this study were stated as it follows.

1. What effect did the instruction period of memory strategies have on students' oral production achievements?

2. Which social strategies did students use while producing oral language, both before and during the DIP?

The hypothesis established as a potential explanation for this phenomenon was as follows: If eleventh graders from a subsidized school are exposed to a period of memory and social strategies instruction, they will improve their oral production achievements $(p \geq .05)$, will be confirmed or refuted in the following section.

\section{Participants}

Participants were 10 eleventh graders in a technical subsidized school in Osorno, Chile. Additionally, these subjects were part of the first cohort of this school which may explain the small number of students. Regarding their English lessons, students officially had three 45-minute lessons per week.

\section{Research Instruments}

Qualitative instruments. Ethnographic field notes played an important role in this investigation since the nature of the study is based on the social sciences. Moreover, eight field notes were taken to increase the credibility of the results. Four of them were collected from the cooperating teacher's lessons (before the DIP), and the remaining four belonged to the student-teacher (the researcher) which were taken throughout the DIP.

The survey consisted of 12 statements in Spanish with the purpose of determining what social and memory strategies students used during the English lessons, the importance of the English language, or how visual input helped them to recall information, and the like.

Quantitative instruments. This test consisted of a face-to-face interview. This instrument provided structured and numerical data aimed at establishing 
students' oral production level. The test was divided into three items, and each of them focused on a particular set of lexical chunks and vocabulary. The first item consisted of ice-breaking questions, the second on students' opinions and agreements, and the third encouraged students to describe an image. Each item had 20 points and was assessed based on criteria that considered fluency, comprehension, grammar, ideas/meaning, and lexical chunks choice.

\section{Data Collection Procedure}

Data for the present study were collected at two points in an academic semester. Four field notes were taken by the cooperating teacher at the beginning of the DIP and four field notes by the pre-service teacher during the DIP. These eight field notes aimed at grasping and analyzing the context of the students and the strategies they used. Then, each participant was given a pre- and post-test and a survey before and after the DIP to establish a comparison between the results and verify or reject the hypothesis.

\section{Results and Discussion}

\section{Description of Pre- and Post-Test Results}

The analysis was based on the result of the preand post-tests, central tendencies and dispersion measures, and Wilcoxon test. The pre- and posttests (the interviews) were divided into three items with a total score of 60 points. Eighty percent of the students who took the pre-test scored less than $50 \%$ which matched with the low level of proficiency reached by students on the standardized tests (English SIMCE test). However, in the post-test, every student increased their results and 8 out of 10 students reached about $60 \%$ of achievement. Additionally, it is important to mention that every student increased at least six points from the preto the post-test, and four of these results increased significantly.

In table 4, central tendencies and dispersion are presented. These results also provide more information about the scores obtained.

Table 3. Pre $\mathcal{E}$ post test results and gains.

\begin{tabular}{cccc}
\hline Students & Pre-test & Post-test & Gain \\
\hline 1 & 40 & 46 & 6 \\
2 & 20 & 34 & 14 \\
3 & 34 & 44 & 10 \\
4 & 33 & 48 & 15 \\
5 & 29 & 42 & 13 \\
6 & 29 & 44 & 15 \\
7 & 31 & 42 & 11 \\
8 & 32 & 42 & 10 \\
9 & 38 & 49 & 11 \\
10 & 19 & 34 & 15 \\
\hline
\end{tabular}

Table 4. Central tendencies and dispersion.

\begin{tabular}{ccc}
\hline & Pre test & Post test \\
\hline Mean & 30.50 & 42.50 \\
Median & 31.5 & 43 \\
Mode & 29 & 42 \\
Standard Dev. & 11.23 & 13.70 \\
\hline
\end{tabular}


Furthermore, a Wilcoxon Signed Rank Test suggested that results were statistically significant ( $p=.00256$ ) therefore confirming the hypothesis $(p \leq .05)$. As such, it can be suggested that implicit social and memory strategy instruction had a positive impact on students' oral production.

\section{Answering Research Questions}

First, the pre-test results indicate that 8 out of 10 students did not reach $60 \%$ of achievement, which is the normal passing requirement in Chile. In addition, the similar results shown in the central tendencies (see table 2) confirm the low results students scored before the intervention period. In terms of the results in every item of the pre-test, students increased their scores in item 1 in which they had to answer questions such as: how are you today? Or how old are you? Nevertheless, students only achieved $60 \%$ of the mean (12 points), and had to ask for repetition or give incomplete answers due to lack or inaccuracy use of vocabulary. To complement this finding, all students completely disagreed with the statement I can easily express ideas in English included in the survey. Thus, these results clearly suggest that students were aware of their lack of speaking skills which did not allow them to express ideas in English on their own. Even when these survey answers concur with the results obtained in the pre-test, the following excerpts provide more evidence found in the cooperating teacher's field notes.

S5: esa de los "shu" todavía no la entiendo $\mathrm{T}$ : tienes que escoger una choose, shoes, should

(The teacher indicates on the board the words)

$\mathrm{T}$ : ok here we go, three. María!

S5: no no si ya voy jajaja

(The student was talking to a classmate)

T: ok, three, two, one

(The second part of the video starts and students

watch and listen to it. This is very short)

S2: eso era todo!!

All: juajaujauajuajauauja

S6: profe no respondí nada!

S2: profe me está molestando jajajajajaja

T: ok, again again. I'll repeat it again

(Excerpt from cooperating teacher's field notes)
T: $\quad$ hay una película que se llama the punisher, punisher

S2: de pana, de pana jajajja

S1: de panadero jajaja

Sts: ajjajajajaja

T: (...) sale el nombre con una calavera acá, the punisher

S2: el pánico, el pánico

S4: Malvado

T: no!

Sts: jajajajajjajajja

T: punish es castigar, ya

S1: re penca el profe ajjajaja

S2: jajajaja mala ondaa jajaja

T: shhh chicos, punish es castigar. She punished them. ¿Ella castigó a quién es?

S4: a ellos

S1: a ellos

(Excerpt from cooperating teacher's field notes)

These excerpts suggest that students were not encouraged to speak English during the lessons or produce at least some ideas in the target language. Therefore, it can be inferred that these students did not have adequate oral proficiency to express ideas and interact with their classmates or the teacher; at least they were not encouraged to do so. In general, students' oral performance before the direct intervention was very low.

The second research question was analyzed based on two criteria considered in the pre-posttest: ideas and meaning, and word choice. The first criterion aimed at identifying the correct use of vocabulary, while the latter aimed at recognizing the use of correct lexical chunks. In both criteria, students' results almost reached the ideal score which shows that most students managed to answer with appropriate utterances such as I agree, I think that, or In my opinion. Therefore, it may be inferred that students used the set of vocabulary stored in their minds to answer adequately, and help their own oral production.

Finally, the last research question set at the beginning of the study was the following: Which social strategies do students use while producing oral language, both before and during the DIP? First, to establish which social strategies students 
used before the direct instruction period, field notes from the cooperating teacher were analyzed. The activities students were encouraged to perform were solving a handout or answering questions written on the board. Therefore, reading and writing were the skills promoted there. This situation can be observed in the excerpt below.

S3: iprofe ¿qué hay que hacer?

$\mathrm{T}: \quad$ ya qué tiene que hacer, Claudio!

S1: completar

T: completar ¿qué?

S1: las oraciones

$\mathrm{T}:$ ya

S2: bieeenn bravo! Jajajaja elbigboss jajaja

Ss: jajajajajaja

T: ok, people let's work. A trabajar.

S2: profe, ¿es en grupo?'

$\mathrm{T}$ : como quieran

(Students start working, some of them individually, some others in pairs. The teacher immediately asks if they have finished)

$\mathrm{T}$ : ready?

S1: sí

T: ¿están listo ya?

S1: see

T: a ver muéstramelo

S1: a pero no en el cuaderno

$\mathrm{T}$ : lo voy a revisar en el cuaderno

(Excerpt taken from cooperating teacher's field notes)

Students often worked on their own, but were also given the choice to work alone, in pairs, or in groups. Since students had not been taught how to take advantage of cooperative learning situations, it is likely that they did not benefit from pair or group work. They were focused on the product rather than on the process, which in this case enhances rules and meta-language instead of skill development. Some other examples can be identified in the following excerpt.

T: los sujetos hacen o realizan esta acción, este verbo a estos (...) cuando tú hagas una acción, ey!

(Students are still laughing)

T: cuando tú hagas una acción, ocupas éstos. Pero la persona que la recibe son éstos' (indicating to the board). Por ejemplo, yo quiero decir eeemmm "nosotros los llamamos a él," "nosotros lo llamamos a él"

(The teacher writes on the board the sentence and most of the students seem to be interested on what the teacher is explaining)

T: ¿cómo sería?

S1: we

T: we

S1: call

T: $\quad$ called, el pasado de call. ¿a él?

S3: he

S2: his

S1: to him

T: no, no es "to" him, solo him. We called him, nosotros lo llamamos.

(Excerpt taken from cooperating teacher's field notes)

Again, students were focused on grammar patterns and rules. In addition, it is clear that a translation approach was part of their classroom routine. Students were not encouraged to develop any speaking skills as they spoke all the time in their L1, which was allowed.

Excerpt 5 shows a group activity that does not establish rules or a clear objective to work together. Moreover, this activity did not demand the explicit development of any skill; quite the contrary, the students again had to work for a product. The cooperating teacher seemed to take for granted that students worked in groups consciously; however, it is evident that they did not know how to do this effectively to foster their learning.

$\mathrm{T}$ : the idea is that today we work on this (The teacher shows a handout)

$\mathrm{T}$ : vamos a trabajar en esto, $\mathrm{y}, \mathrm{y}, \mathrm{y}$, la idea es que ojalá trabajen en parejas y a conciencia porque la prueba va a ser copiar y pegar de esto, control $\mathrm{C}$, control $\mathrm{V}$, ya? $\mathrm{O}$ en grupo de a tres si quieren, siempre y cuando trabajen. One, two, three, four (The teacher started to form each group)

S11: nooopo profe como va a andar Armando los grupos po..

(Finally students gather in groups as they want. There is not group work at all, they just sat together.) 
T: ok, los voy a dejar con la primera parte un poquito, la segunda la vamos a resolver todos juntos. Es poquito!'

(Excerpt from cooperating teacher's field notes)

In short, there was not any activity that promoted oral production at all or the use of social strategies. To strengthen these findings, the analysis of the statement, I learn more when I work in groups, from the survey applied before the DIP, revealed that $80 \%$ of the students disagreed and $20 \%$ remained indifferent to this idea. This is consistent with the null training in social strategies and cooperative work observed in the cooperating teacher's data. Moreover, field notes from the student-teacher were analyzed to identify the social strategies used by the students during the intervention period. The following excerpt reveals that most of the activities intended to promote collaborative work through social strategies and develop speaking skills.

ST: yes! Gather in groups and finish your work, you have 10 minutes to finish this, ok. Remember that yesterday I gave you some guidelines, some steps, right?

S4: algunos pasos??

ST: yes, you have to follow steps, and everybody has to work. Remember if you don't know something try to discuss it in your groups

S2: discutir?

ST: jajaja no no, share! Remember share with your partner, here you have to share ideas

S1: compartir

ST: yes

(Excerpt taken from student teacher's field notes)

This activity is clearly devoted to promoting oral speech through social strategies. There is a purpose for working together, and they seem motivated to accomplish this task helped by their classmates.

\section{Conclusion}

This research contributes to the study of speaking improvement by providing a new perspective for the use of social strategies encouraging students to use them implicitly when working collaboratively on speaking tasks. This research supports the idea that memory strategies facilitate students' vocabulary learning; nevertheless, improving students' oral production might be enhanced only if these two elements are developed together.

Notwithstanding the positive results, the study did have some limitations. To begin, the low level of English that students had before the intervention period hampered the initial plan of action. From the observations and pre-test results, it was evident that the contents of the lessons had to be simplified. Furthermore, the different approaches fostered by the cooperating teacher and the student teacher caused some difficulties at the beginning of the process. Specifically, the teaching style transitioned from a structuralist approach to a more communicative one.

Some suggestions for further research would be to replicate this study with a more proficient and bigger sample group which could offer a comparison and verify if the results remain.

\section{References}

Demirezen, M. (2011). The foundations of the communicative approach and three of its applications. Journal of Language \& Linguistics Studies, 7(1), 57-71.

Ellis, R. (1997). Second language acquisition. Oxford: Oxford University Press.

Finocchiaro, M., \& Blumfit, C. (1983). Functional-notional approach: From theory to practice. Oxford: Oxford University Press.

Hedge, T. (2000). Teaching and learning in the language classroom. Oxford. Oxford University Press.

Johnson, R. B., Onwuegbuzie, A. J., \& Turner, L. A. (2007). Toward a definition of mixed methods research. Journal of Mixed Methods Research, 1, 112.

Krashen, S. (1993). The power of reading. Englewood, CO: Libraries Un-limited.

Lazaraton, A. (2001). Teaching oral skills. In M. CelceMurcia (Ed.). Teaching English as a second foreign language (pp. 103-115). Boston: Heinle and Heinle.

Ministerio de Educación. (2012). Resultados SIMCE III Medio 2012 Inglés. Santiago, Chile.

Oxford, R. (1990). Language learning strategies: What every teacher should know. Boston: Heinle \& Heinle. 
Oxford, R. L. (2003). Language learning styles and strategies: Concepts and relationships. International Review of Applied Linguistics in Language Teaching, 41, 271-277.

Richards, J. (2008). Teaching listening and speaking: From theory to practice. Cambridge: Cambridge University Press.

Richards, J., \& Rogers, T. (2001). Approaches and methods in language teaching. Cambridge: Cambridge University Press.

Slotnick, S. D., Thompson, W. L., \& Kosslyn, S. M. (2012). Visual memory and visual mental imagery recruit common control and sensory regions of the brain. Cognitive Neuroscience, 3(1), 14-20.

Schneider, W., Kron-Sperl, V., \& Hünnerkopf, M. (2009). The development of young children's memory strategies: Evidence from the Würzburg longitudinal memory study. European Journal of Developmental Psychology, 6(1), 70-99.

Thornbury, S. (2010). How to teach speaking. Harlow, United Kingdom: Pearson Education Press.

Richards, J. (2015). Developing classroom speaking activities: From theory to practice. Retrieved May 23, 2017, from https://www.researchgate.net/ publication/237701015 Developing Classroom Speaking_Activities_From_Theory_to_Practice 